\title{
High virucidal potential of novel ceramic-metal composites fabricated via hybrid selective laser melting and spark plasma sintering routes
}

\author{
Ramin Rahmani $^{1,2} \cdot$ Katja Molan $^{3} \cdot$ Miha Brojan $^{2} \cdot$ Konda Gokuldoss Prashanth $^{1,4,5} \cdot$ David Stopar $^{3}$
}

Received: 19 November 2021 / Accepted: 2 February 2022 / Published online: 8 February 2022

(c) The Author(s), under exclusive licence to Springer-Verlag London Ltd., part of Springer Nature 2022

\begin{abstract}
In this work, we combine selective laser melting (SLM) and spark plasma sintering (SPS) to fabricate new materials with high virucidal potential. Various bioactive disc-shaped ceramics, metal alloys, and composites were fabricated and tested against bacteriophage Phi6 - a model system for RNA-enveloped viruses. We prepared silver-doped titanium dioxide $\left(\mathrm{TiO}_{2}+2.5-10 \% \mathrm{Ag}\right)$, copper-doped titanium dioxide $\left(\mathrm{TiO}_{2}+2.5-10 \% \mathrm{Cu}\right), \mathrm{Cu} 2 \mathrm{NiSiCr}$, and $\mathrm{Cu} 15 \mathrm{Ni} 8 \mathrm{Sn}$ composite materials (metal lattices filled with ceramics). The virucidal tests of the ceramic and metal powders were performed in buffered suspensions, while the surfaces of the discs were tested by swabbing. The results show that the virus titer on the $\mathrm{TiO}_{2}+10 \%$ $\mathrm{Ag}$ ceramic and $\mathrm{CuNi} 2 \mathrm{SiCr}$ metal discs decreased by 4 logs after $15 \mathrm{~min}$ of exposure to the surfaces compared to the control ceramic and steel discs. We show that SLM 3D printed pre-alloyed CuNi2SiCr filled with bioactive $\mathrm{TiO}_{2}+10 \% \mathrm{Ag}$ nanopowders and sintered by the SPS process combines the simplicity of printing with the strength and virucidal properties of $\mathrm{Ag}$ and $\mathrm{Cu}$ materials. The proposed new virucidal materials were also used for the fabrication of prototype elevator buttons.
\end{abstract}

Keywords Selective laser melting $\cdot$ Powder bed fusion $\cdot$ Spark plasma sintering $\cdot$ Phi6 virus $\cdot$ Virucidal materials

\section{Introduction}

With the emergence of new technologies, such as SLM and SPS, it is now possible to fabricate metal matrix composites (MMC) consisting of a filled ceramic oxide or refractory material, such as titanium dioxide, hydroxyapatite, diamond, tungsten carbide, embedded in metal alloys, such as Ti-, Fe-,

Ramin Rahmani

ramin.rahmaniahranjani@taltech.ee;

ramin.rahmaniahranjani@gmail.com

1 Department of Mechanical and Industrial Engineering, Tallinn University of Technology, Ehitajate tee 5, 19086 Tallinn, Estonia

2 Laboratory for Nonlinear Mechanics, Faculty of Mechanical Engineering, University of Ljubljana, Aškerčeva cesta 6, 1000 Ljubljana, Slovenia

3 Department of Microbiology, Biotechnical Faculty, University of Ljubljana, Večna pot 111, 1000 Ljubljana, Slovenia

4 Erich Schmid Institute of Materials Science, Austrian Academy of Science, Jahnstraße 12, 8700 Leoben, Austria

5 CBCMT, School of Mechanical Engineering, Vellore Institute of Technology, 632014 Vellore, Tamil Nadu, India
$\mathrm{Cu}$-, and Al-based in bulk or lattice form. SPS provides one of the highest consolidation-densification results and can be optimized for ceramics (e.g., $\mathrm{TiO}_{2}$ or $\mathrm{ZrO}_{2}$ ) in powder metallurgy. Consequently, the fabricated MMC materials can have designed ductility, elastic modulus, strength, and resistance to various mechanical stresses such as impact, compression, wear [1-4], etc. In addition, innovative high-tech materials can be used in new and unforeseen applications. For example, new materials can have better virucidal properties, which are in high demand due to the recent global virus crisis.

The antimicrobial and virucidal activity of $\mathrm{Cu}$ has been known and exploited since ancient times [5]. For example, it has been shown that SARS-CoV-1 and SARS-CoV-2 can be inactivated in less than $4 \mathrm{~h}$ on $\mathrm{Cu}$ surfaces, while they persist for $48-72 \mathrm{~h}$ on stainless steel $[6,7]$. In many settings, frequently touched surfaces, such as door handles/knobs, light switches and elevator panels/buttons, bed rails, and restroom tap handles, may become contaminated with viruses on a daily basis. Therefore, virucidal materials can be used to diminish the spread of viruses or to decontaminate these surfaces (such surfaces are often referred to as self-cleaning surfaces). But 3D printing pure copper is very challenging due to building orientation and thermal distortions. On 
the other hand, the alloying of copper reduces electrical conductivity and can facilitate the fabrication of virucidal surfaces [8]. While the high thermal conductivity and low laser absorption make sintering of pure copper powder difficult [9], good mechanical properties (78 HRB hardness and $399 \mathrm{MPa}$ yield strength at $220 \mathrm{~J} / \mathrm{mm}^{2}$ laser energy density) can be obtained for Cu10Sn by SLM [10]. In this way, when $\mathrm{Cu}$ alloys are used instead of pure $\mathrm{Cu}$, a small amount of electro-thermal conductivity is sacrificed to achieve better flowability and printability.

Silver particles have been shown to inhibit many viruses, including the bacteriophage Phi6, as well as herpes simplex, human parainfluenza type-3, vaccinia, respiratory syncytial, tacaribe, and hepatitis B [11-14]. Silver can be incorporated into metal alloys in the form of nanoparticles with welldefined shapes and varied particle sizes, which determines its toxicity and bioactivity [15]. However, the virucidal properties of ceramic/metal alloys formed from ceramic or metal lattices filled with silver nanoparticles remain unexplored. Nevertheless, silver particles have been successfully integrated into $\mathrm{TiO}_{2}+\mathrm{Ag}$ ceramics and $\mathrm{Ti} 6 \mathrm{Al} 4 \mathrm{~V}-\mathrm{TiO}_{2}+\mathrm{Ag}$ composites by combining SPS and SLM techniques [1].

In this work, we propose several new materials based on powder technology using SLM and SPS, see Rahmani et al. $[16,17]$ for more details on the technology. The new materials were characterized in terms of their material properties using SEM microscopy. All materials and their constitutive parts were tested for their virucidal activity against bacteriophage Phi6. The bacteriophage Phi6 is a well-characterized enveloped RNA virus [18-23] and an established model system for virucidal testing. It has been used as a model system for studying eukaryotic viruses such as Ebola [24], H5N1 [25], and coronaviruses [24, 26]. We tested the ability of the new materials to reduce viral titer during a brief $15 \mathrm{~min}$ exposure to the newly fabricated metal surfaces. The results indicate that several of the newly fabricated ceramic-metal composites produced by hybrid powder bed fusion and powder metallurgy have exceptionally good virucidal potential. Consequently, pre-alloyed $\mathrm{CuNi} 2 \mathrm{SiCr}$ materials $3 \mathrm{D}$ printed by SLM, then filled with bioactive $\mathrm{TiO}_{2}+10 \% \mathrm{Ag}$ nanopowders and sintered by SPS process could lead to metal and ceramic products with improved mechanical and virucidal properties.

\section{Materials and methods}

\subsection{Applied technologies}

Compared to classical subtractive manufacturing, SLM offers wider opportunities, such as near-net-shape fabrication, shorter production time, avoidance of unnecessary post-processing, acceptable mechanical properties, direct reading of CAD models (especially for complex geometries), and parallel production (one platform with simultaneous 3D-printing of numerous models). The SLM process is a laser-based powder bed fusion (PBF) process that can produce lattice/scaffold structures, triply periodic minimal surfaces (TPMS), and complex assemblies due to the ability to deposit layer by layer with defined point spacing. SLM allows the application of a wide range of different parameters, such as scanning speed, laser power, scanning strategy, layer thickness, powder size/shape/flowability, absorption/transmission of laser energy, rapid consolidation/melting of materials, and evaluation of microstructure [27, 28]. The use of virgin and recycled powders has an impact on the surface morphology, microstructure, mechanical properties, hardness, and porosity of the additive manufactured parts slightly changes [29].

Powder metallurgy (PM) has recently been upgraded toward subtractive/additive manufacturing approaches. SPS, for example, is becoming more commonly used in PM due to its ability to sinter a wide range of materials from ceramics to metals and glasses, its ability to produce dense materials with reduced grain growth due to the simultaneous temperature-pressure program, and it takes a shorter time compared to isostatic hot pressing. In SPS, heat generation sintering is induced by a DC voltage pulse that generates spark plasma and Joule heating due to resistance to electric current. The SPS device allows control of pressure, ramp rate, holding time, pulse duration, sintering temperature, and current/voltage, enabling consolidation of any type of powder without tangible grain growth (high densification) and rapid prototyping of materials (metal alloys and ceramic oxides) [30, 31].

\subsection{Work flow}

In this study, we propose a combined SLM-SPS approach. Material and parameters are optimized (laser power, scanning speed, and layer thickness for SLM; temperature, pressure, and sintering time for SPS) and repeated 3 times to reduce possible risks of real application failure [32-34]. The graphical summary (Fig. 1) outlines the methodology. The flexibility of this method allows us to use a metallic matrix (including solid, porous, or partially variable from bulk to lattice) with different volume fractions and a wide range of filled ceramics (which can be replaced by polymers) with a focus on the application. Depending on the application (e.g., biomedical, antiviral, tribological, thermal/electrical), different mechanical characterizations can be performed, such as impact, abrasion, compression, in vivo, and in vitro qualifications or environmental conditions. 
Fig. 1 Graphical abstract for virucidal material processing via SLM and SPS

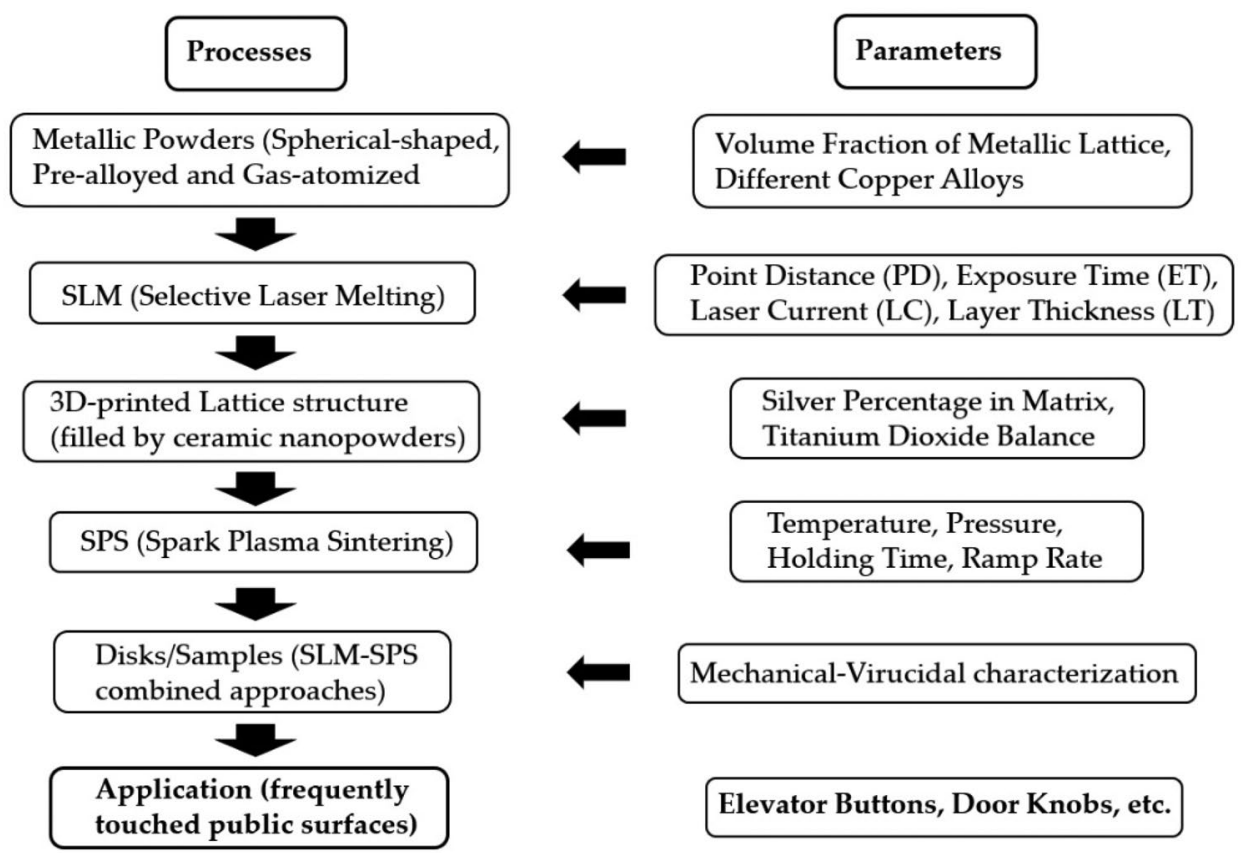

\subsection{Materials}

Powders used included $\mathrm{TiO}_{2}$ anatase (ABCR GmbH, Germany, BET surface area of $150 \mathrm{~m}^{2} / \mathrm{g}$ ), silver nanoparticles (ABCR GmbH, 99.95\% purity), copper (Sigma-Aldrich, 99.5\% trace metal base, USA), and also powders with spherical particles and high flowability made specifically for AM devices, including CuNi2SiCr (TLS Technik GmbH, Germany, 10-63 $\mu \mathrm{m}$ ), Ti6Al4V (TLS Technik $\mathrm{GmbH}, 15-45 \mu \mathrm{m}$ ), and 316L (SLM Solutions AG, reference, $10-45 \mu \mathrm{m})$. Different powders were used to fabricate the virucidal materials. Anatase supplemented with virucidal silver ions $\left(\mathrm{TiO}_{2}+10 \% \mathrm{Ag}\right)$, anatase supplemented with $\mathrm{Cu}$ ions $\left(\mathrm{TiO}_{2}+10 \% \mathrm{Cu}\right), 316 \mathrm{~L}$, pure copper powder, and pre-alloyed gas-atomized copper powders $(\mathrm{CuNi} 2 \mathrm{SiCr}$, $\mathrm{Cu} 15 \mathrm{Ni} 8 \mathrm{Sn})$. The powders exhibited different sizes and shape distributions of nanoparticles, as shown in Fig. 2. In our experience, silver flakes are cost-effective fillers and provide better adhesion than conventional nanoparticles. The pure copper powder does not absorb laser energy due to its high thermal reflectance and reflects it back to the source. Other problems such as rapid heat dissipation in the molten region and layer separation due to high thermal gradients have been reported in the literature [35]. Instead, copper-balanced $\mathrm{CuNi} 2 \mathrm{SiCr}$ is a spherical-shaped, lowalloyed, and gas-atomized copper alloy synthesized for 3D printing applications with high flowability and stiffness in the range of $10-63 \mu \mathrm{m}$. It is the most commercially used copper alloy (with $<95 \%$ copper) on the market for SLM processes [36].

\subsection{Discs production by SPS and bulk/lattice structures by SLM}

Titanium dioxide mixed with different percentages of silver and copper was consolidated by spark plasma sintering (FCT Systeme GmbH, Germany), which takes place in a vacuum glove-box chamber and a flow of nitrogen [37, 38]. All ceramic discs were produced in a $20 \mathrm{~mm}$ diameter graphite mold under a pressure of $50 \mathrm{MPa}$ and a ramp rate of $100{ }^{\circ} \mathrm{C} / \mathrm{min}$ during the process with a defined powder mixture and optimized SPS parameters. $6 \mathrm{~g}$ of ball-milled $\mathrm{TiO}_{2}+2.5-10 \% \mathrm{Ag}$ powder was plasma sintered at $750{ }^{\circ} \mathrm{C}$ temperature and 25 min dwelling time. A total of $7 \mathrm{~g}$ of the $\mathrm{TiO}_{2}+2.5-10 \% \mathrm{Cu}$ ceramic mixture was plasma-sintered at $780{ }^{\circ} \mathrm{C}$ with a holding time of $20 \mathrm{~min}$. For our metal discs, a higher amount of powder $(20 \mathrm{~g})$ and a lower holding time for sintering ( $5 \mathrm{~min}$ ) were used. The sintering temperature was $1000{ }^{\circ} \mathrm{C}$ for $316 \mathrm{~L}, 780{ }^{\circ} \mathrm{C}$ for $\mathrm{Cu} 15 \mathrm{Ni} 8 \mathrm{Sn}, 800{ }^{\circ} \mathrm{C}$ for pure $\mathrm{Cu}$, and $820^{\circ} \mathrm{C}$ for CuNi2SiCr. A Realizer SLM50 device (SLM solutions AG, Germany) based on AM technology was used to fabricate 3D printed bulk or lattice structures $[39,40]$. For the two Ti6Al4V bulk samples, the following parameters were optimized: $25 \mu \mathrm{m}$ point distance, exposure time of $25 \mu \mathrm{s}$, laser current of $2500 \mathrm{~mA}, 60 \mathrm{~W}$ laser power, $1000 \mathrm{~mm} / \mathrm{s}$ scan speed, $60 \mu \mathrm{m}$ hatch distance, and $25 \mu \mathrm{m}$ layer thickness with an argon gas flow during laser sintering. For the $\mathrm{CuNi} 2 \mathrm{SiCr}$ lattice structure, due to its high thermal conductivity and reflectivity, we reduced the speed of the recoater to give the structure time to cool/consolidate. The optimized parameters for $\mathrm{CuNi} 2 \mathrm{SiCr}$ were: $25 \mu \mathrm{m}$ point 
Fig. 2 SEM micrograph of powders used for the fabrication of virucidal materials: (A) $\mathrm{TiO}_{2}-10 \% \mathrm{Ag},(\mathbf{B}) \mathrm{TiO}_{2}-10 \%$ $\mathrm{Cu},(\mathbf{C})$ copper (pure metal powder), and (D) $\mathrm{CuNi} 2 \mathrm{SiCr}$ (pre-alloyed gas-atomized copper powder)
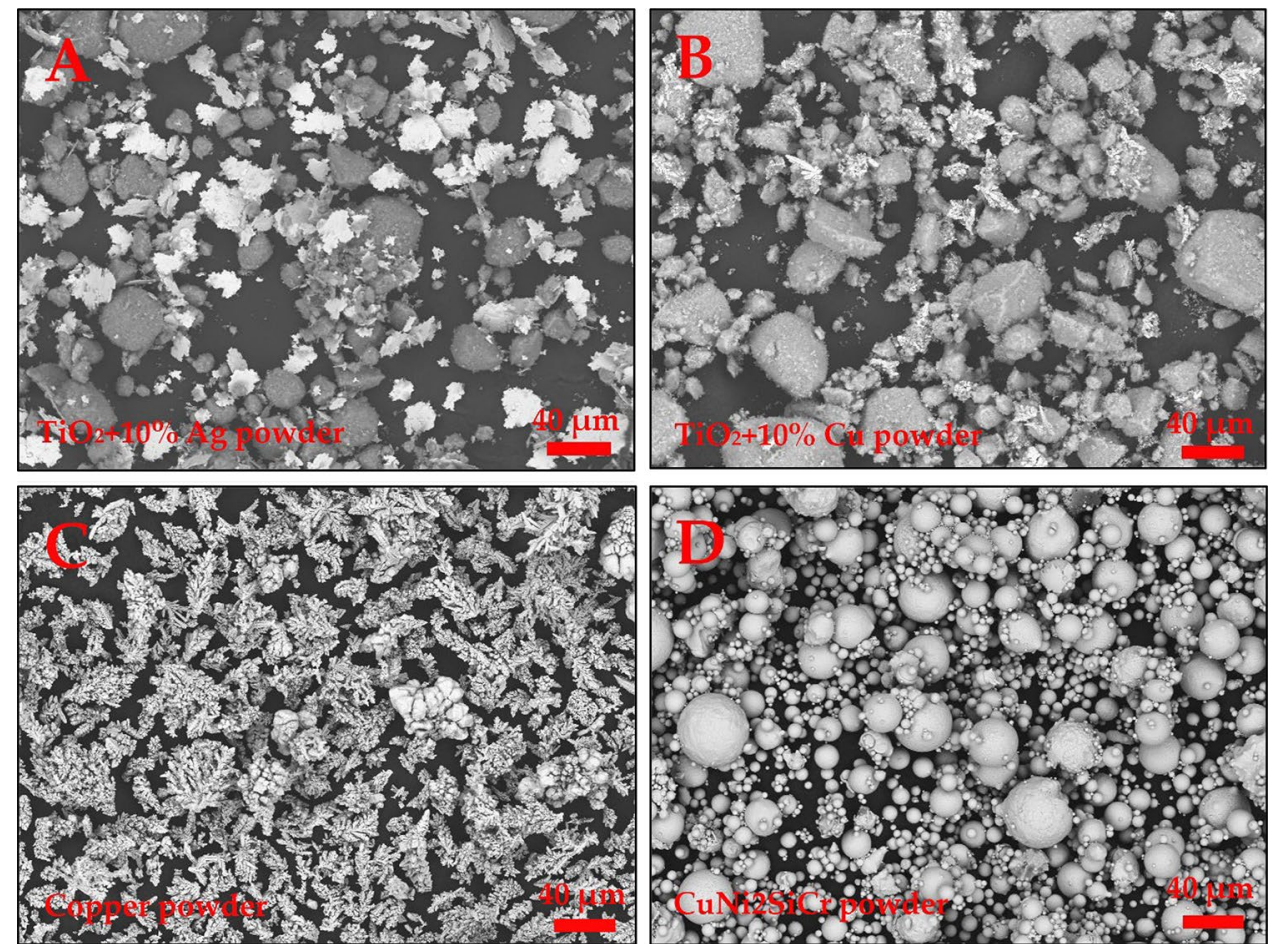

distance, exposure time of $25 \mu \mathrm{s}$, laser current of $3000 \mathrm{~mA}$, $60 \mathrm{~W}$ laser power, $1000 \mathrm{~mm} / \mathrm{s}$ scan speed, $60 \mu \mathrm{m}$ hatch space, and $25 \mu \mathrm{m}$ layer thickness with a gas flow of argon during the laser sintering. The key point is to use a lower speed of the recoater and not to use sieved particles. These parameters are valid for both lattice and bulk structure and in SLM50 or SLM280 (Lab or Industry series) 3D printers.

\subsection{Concept design of 3D printed samples}

We propose new composite (bulk or porous) structures of $\mathrm{Cu}$-alloyed (CuNi2SiCr or Cu15Ni8Sn) and Ti-alloyed (Ti6Al4V or Ti22Al25Nb) filled with titanium dioxidebased $\left(\mathrm{TiO}_{2}+\mathrm{Ag}\right.$ or $\left.\mathrm{TiO}_{2}+\mathrm{Cu}\right)$ to achieve virucidal, antibacterial, or antiadhesive properties, reduce deposition of bacteria and viruses, improve impact-compression resistance, and to improve mechanical and tribological properties. Ti6Al4V-TiO $2+10 \%$ Ag and $\mathrm{CuNi} 2 \mathrm{SiCr}-\mathrm{TiO}{ }_{2}+10 \% \mathrm{Ag}$ composites are developed here by a combination of SLMmelted metal lattice and SPS-sintered embedded ceramics and polishing with P800 sandpaper. The SLM parameters have already been mentioned above, but the SPS parameters for the composites are slightly different from those for pure ceramic or metal material. Regarding the melting point of the metal alloy (mostly balanced metal), the SPS temperature was 1000 and $750{ }^{\circ} \mathrm{C}$ for the aforementioned metalceramic composites. Time and pressure were set at $20 \mathrm{MPa}$ and $10 \mathrm{~min}$, respectively, for both cermet composites.

\subsection{Measurement of surface free energy (SFE)}

Great care was taken to prepare the surfaces of the samples consistently. Prior to SFE measurements, the discs were sonicated in an ultrasonic bath for $20 \mathrm{~min}$ to remove potential remains/debris on the disc surface, washed with ethanol, dried, and used for surface free energy measurements. Contact angle measurements were performed using an MSA mobile surface analyzer (Krüss $\mathrm{GmbH}$, Germany). Measurements were performed with $2 \mu \mathrm{L}$ droplet volume and $1 \mathrm{~s}$ equilibration time under constant conditions. Deionized water and diiodomethane (CH2I2) served as test liquids with different polarities to calculate the surface free energy according to the OWRK (Owens, Wendt, Rabel, and Kaelble) method [41-43]. The surface free energy (SFE) with its components (polar and dispersive) was calculated using Krüss Advance v. 1.9.2 software.

\subsection{Virucidal testing}

All experiments for virucidal testing were performed with an overnight culture of bacteria Pseudomonas sp. (DSM 21,482) and bacteriophage Phi6, which were obtained from Leibniz Institute (Germany). The bacteria were cultured in TSB media at $28{ }^{\circ} \mathrm{C}, 180 \mathrm{rpm}$ overnight $1 \%$ of the inoculum was then added to fresh TSB media and grown to an exponential phase. Phage Phi6 was enriched as previously described [44]. The phage stock was prepared by centrifugation at $100,000 \mathrm{~g}$ for $2 \mathrm{~h}$ at $4{ }^{\circ} \mathrm{C} \mathrm{[45]} \mathrm{to} \mathrm{obtain} \mathrm{a} \mathrm{viral} \mathrm{titer}$ 
of $\sim 10^{10}$, which was used for virucidal testing. The phage suspension was stored at $4{ }^{\circ} \mathrm{C}$ until further use. The effect of materials on virus viability was determined using the double agar overlay plaque assay [46] by enumeration of bacteriophages before and after exposure of viruses to the different materials and calculated as PFU [plaque forming units/(volume of phage added $\times$ bacteriophage dilution)]. The virucidal tests for a given material were performed independently at least three times.

\subsection{Powder testing}

The powders were added to Milli-Q water to give a final concentration of $0.5 \mathrm{M}(\mathrm{mol} / \mathrm{L}) \mathrm{CuNi} 2 \mathrm{SiCr}$ powder suspension, $0.12 \mathrm{M} \mathrm{TiO}_{2}+10 \% \mathrm{Ag}$, and $2.6 \mathrm{M} \mathrm{TiO}_{2}+10 \% \mathrm{Cu}$ powder suspensions to ensure supersaturation of the suspensions. Since the mass of the added powders was at or above the solubility limit, the suspensions were sonicated and mixed before use. Using the dilutions in MQ water, we prepared powder suspensions at concentrations ranging from 0.1 to $400 \mathrm{~mm}$. For all experiments, $10 \mu \mathrm{L}$ of the stock phage suspension was diluted in $490 \mu \mathrm{L}$ of powder suspensions. After $15 \mathrm{~min}$ of incubation at room temperature (without mixing, under light conditions), the phage-powder suspensions were serially diluted and analyzed for viral titers.

\subsection{Discs testing}

The disc testing protocol is shown schematically in Fig. 3. Five droplets containing $10 \mu \mathrm{L}$ of phage stock suspension were placed on the disc surface and incubated for $15 \mathrm{~min}$ at room temperature (without mixing, under light conditions), after which the liquid was removed. After an additional
$1 \mathrm{~min}$, the surface was swabbed with a cotton swab soaked in $100 \mu \mathrm{L}$ PBS buffer and additionally with a dry cotton swab to completely collect detached viruses on the surface. Both wet and dry swabs were placed in a microcentrifuge tube containing $400 \mu \mathrm{L}$ PBS and vortexed for $10 \mathrm{~s}$ to detach the virus particles from the swabs. A total of $100 \mu \mathrm{L}$ of the undiluted PBS solution or $500 \mu \mathrm{L}$ of the diluted PBS solution with detached virus particles were used to infect the bacterial cells and determine the viral titer after exposure to the disc surface. In parallel, to determine the residual viruses left on the swabs, both cotton swabs were placed on TSA agar plates and doused with soft agar containing the inoculum of the bacteria. After overnight incubation at $28{ }^{\circ} \mathrm{C}$, the TSA plates were counted for PFU. The viral titer was calculated and compared to the reference $\left(\mathrm{TiO}_{2}\right.$ - anatase $)$ and control (stainless steel-316L) surfaces. TSA plates with cotton swabs were photographed and visually compared.

\section{Results and discussion}

\subsection{Virucidal effect of powders}

The virucidal effects of different powders are shown in Fig. 4. The concentration series of $\mathrm{TiO}_{2}+\mathrm{Ag}$ and $\mathrm{CuNi}-$ $2 \mathrm{SiCr}$ powders had a very strong virucidal effect on bacteriophage Phi6. With increasing powder concentration, the viral titer decreased by more than 4 logarithms compared to the untreated phage Phi6. A decrease in viral infectivity by $4 \log$ s corresponds to a $99.99 \%$ decrease in the viral titer, indicating good virucidal activity [47]. $\mathrm{CuNi}_{2} \mathrm{SiCr}$ powder had higher activity $(-3.8 \log$ PFU/log $\mathrm{M})$ compared to $\mathrm{TiO}_{2}+\mathrm{Ag}$ powder $(-2.1 \log \mathrm{PFU} / \log \mathrm{M})$. On the other hand,
Fig. 3 Methodology of virucidal disc testing

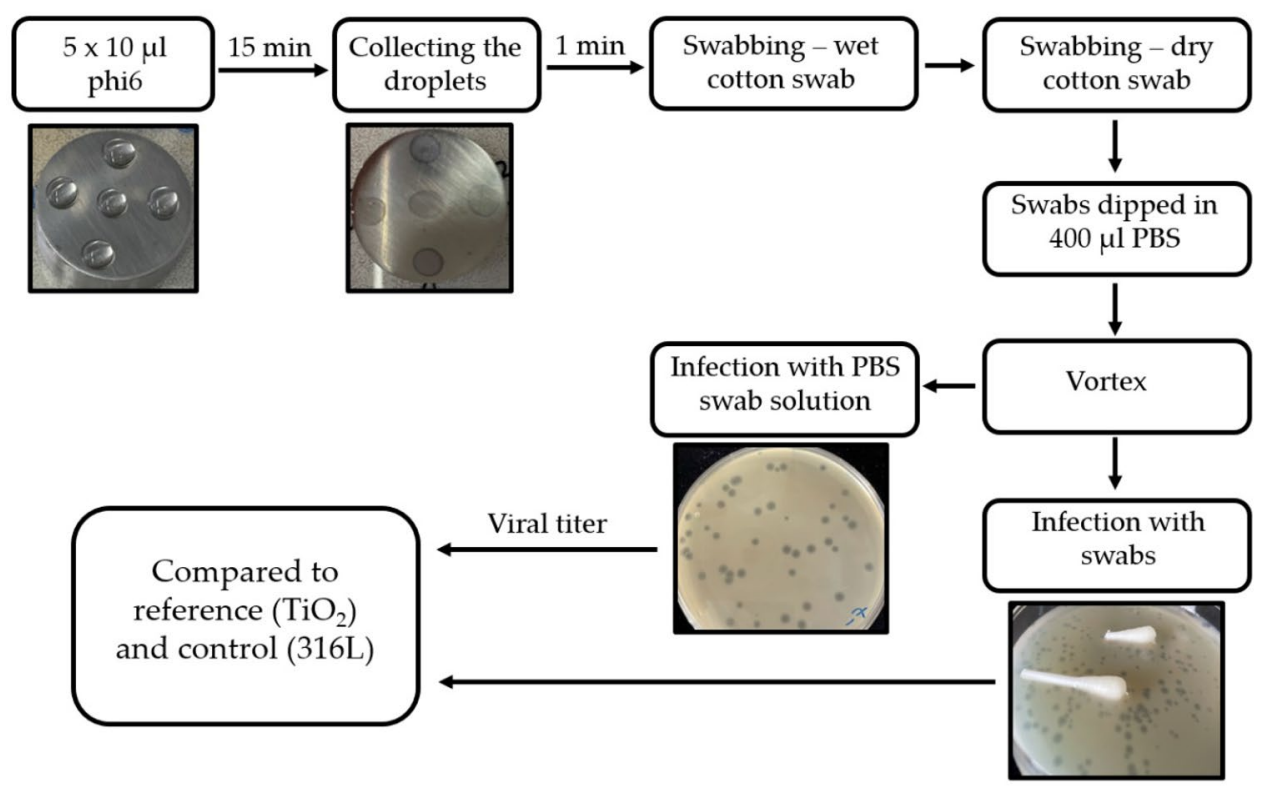




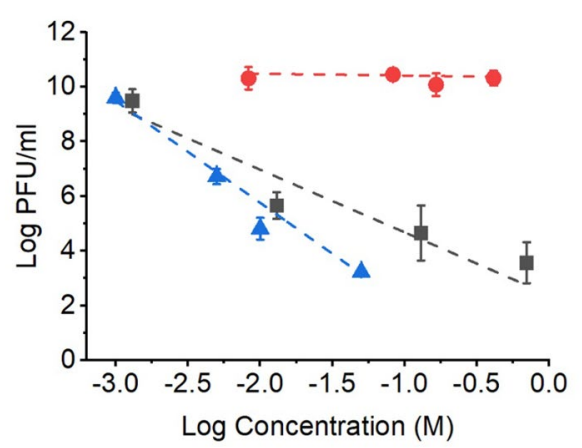

- CuNi2SiCr powder - $\mathrm{TiO}_{2}+10 \%$ Ag powder $-\mathrm{TiO}_{2}+10 \% \mathrm{Cu}$ powder

Fig. 4 Effect of different powder concentrations $(\mathrm{mol} / \mathrm{L})$ on phage Phi6 viral titer. The initial virus titer was $10^{10} \mathrm{PFU} / \mathrm{mL}$. The decline in virus titer was linearly fitted. Average values \pm standard deviations $(n \geq 3)$ are given

$\mathrm{TiO}_{2}+\mathrm{Cu}$ powder had no effect on viral titer. It was shown that $\mathrm{mm}$ (millimolar) concentrations of copper sulfate were required to decrease Phi6 viral titer by 4 logs, and it was suggested that the ionic activity was lower in the powder suspension compared to the metal solutions [48].

\subsection{Spark plasma sintered discs}

Different spark plasma sintered discs are shown in Fig. 5. The samples have a $20 \mathrm{~mm}$ diameter and a height between 3 and $6 \mathrm{~mm}$. With increasing the percentage of $\mathrm{Ag}$ ions in the powder mixture, the sample discs are getting visually darker and the hardness is decreased (varied $\sim 800$ to $700 \mathrm{~kg} /$ $\mathrm{mm}^{2}$ in HV500). With the increasing concentration of $\mathrm{Cu}$ ions, the sample discs are also darker and show some cracks which start from the edges and continue through the center. This indicates that the risk of fracture problems is high for $\mathrm{TiO}_{2}+\mathrm{Cu}$ ceramics compared with the $\mathrm{TiO}_{2}+\mathrm{Ag}$-based samples. Pure $\mathrm{Cu}$ (metallic samples shown in Fig. 5C) is known for its thermo-electro-mechanical properties that have virucidal properties. On the other hand, $\mathrm{Cu}$ alloys have rarely been studied, especially in the field of additive manufacturing. $\mathrm{Cu} 15 \mathrm{Ni} 8 \mathrm{Sn}$ and $\mathrm{Cu} 2 \mathrm{NiSiCr}$ are pre-alloyed $\mathrm{AM}$ materials that will receive more attention in $3 \mathrm{D}$ printing applications in the future.

SEM micrographs of different discs (introduced in Fig. 5) materials are shown in Fig. 6. Micrographs for $\mathrm{TiO}_{2}+\mathrm{Ag}$ ceramics (Fig. 6A-D) show the uniform distribution of silver grains on the surface and in the volume, which are connected like chains. In $\mathrm{TiO}_{2}+\mathrm{Cu}$ ceramics (Fig. $6 \mathrm{E}-\mathrm{H}$ ), $\mathrm{Cu}$ appears as scattered colonies. With the increased percentage of $\mathrm{Cu}$-doped $\mathrm{TiO}_{2}$, we observed the formation and propagation of cracks. The symmetrical cracks were deeper at the edge and extended into the center of the cylindrical samples.

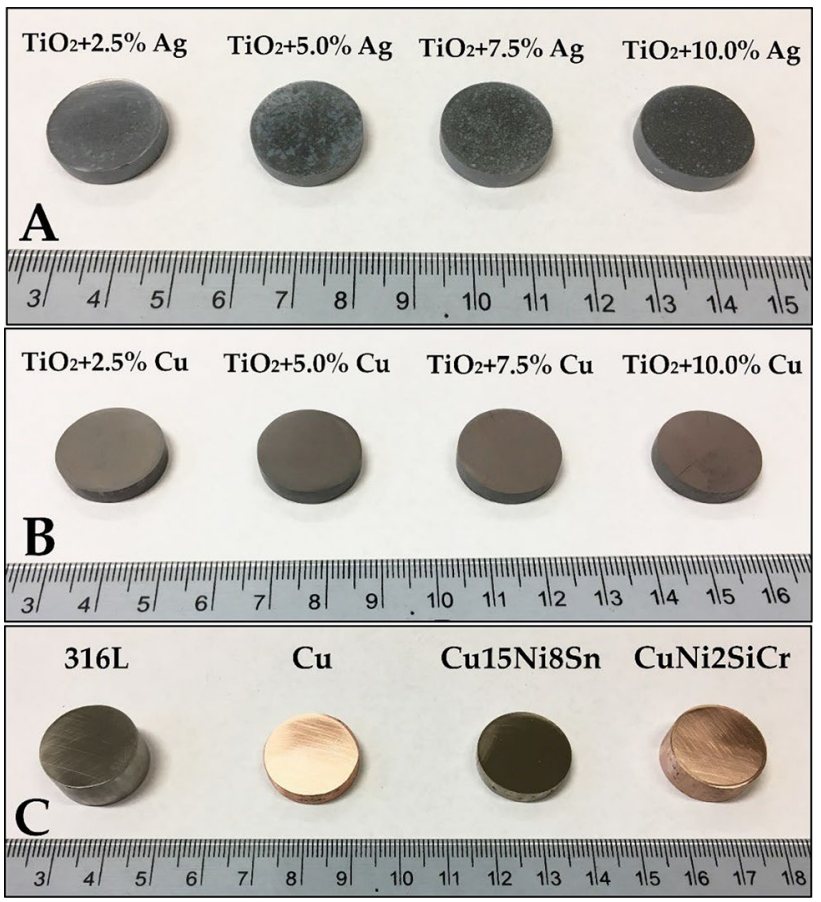

Fig. 5 Photographs of (A) silver-doped titanium dioxide $2.5-10 \%$ discs, (B) copper-doped titanium dioxide $2.5-10 \%$ discs, and (C) metallic sample discs manufactured by SPS device ( $20 \mathrm{~mm}$ diameter)

\subsection{Virucidal effect of spark plasma sintered discs}

The virucidal effects of different disc surfaces are shown in Fig. 7. On the surfaces of $\mathrm{TiO}_{2}$ anatase and steel $316 \mathrm{~L}$ (reference discs), the titers of the recovered viruses after $15 \mathrm{~min}$ of exposure were in the order of $10^{7} \mathrm{PFU} / \mathrm{mL}$. This suggests that some viruses (approximately 1000 per disc) either attached to the reference surface irreversibly and could not be removed from the surface by swabbing, remained attached to the swabs, or the reference material was virucidal. Swabbing was used to simulate the effect of touching the surface with moist human fingers. Significantly higher drops of viral titers were obtained on $\mathrm{CuNi} 2 \mathrm{SiCr}$, Ag-doped $\mathrm{TiO}_{2}$, and pure $\mathrm{Cu}$ discs where viral titer dropped for more than 5 logarithms compared to the initial viral titer of $\sim 10^{10}$ (Fig. 7), indicating that spark plasma sintered disc surfaces have virucidal effectiveness.

To test whether viruses remained attached to the swabs, we incubated the swabs on agar plates (Fig. 8). Swabs from reference $\mathrm{TiO}_{2}$ and control $316 \mathrm{~L}$ steel discs contained infective bacteriophages that prevented bacterial growth on agar plates. This explains the initial drop from $10^{10}$ to $10^{7} \mathrm{PFU} / \mathrm{mL}$ on the disc. On the other hand, the number of residual infective viruses was significantly reduced on swabs from $\mathrm{TiO}_{2}+\mathrm{Ag}(2.5-10 \% \mathrm{Ag})$, $\mathrm{TiO}_{2}+\mathrm{Cu}(2.5-10 \% \mathrm{Cu})$, and pure $\mathrm{Cu}$ disc surfaces. This confirms the previous results of the virucidal effects of the 
Fig. 6 SEM micrograph of $\mathrm{TiO}_{2}$ doped with different $\mathrm{Ag}$ concentrations: (A) 2.5, (B) 5, (C) 7.5, and (D) $10 \%$. SEM micrograph of $\mathrm{TiO}_{2}$ doped with $10 \% \mathrm{Cu}$ : (E-H). Different view fields and magnifications are shown due to sample inhomogeneity $\mathrm{Cu}$ doped ceramic discs. For example, in (G) crack at the edge of the sample (problematic), and (H) cracks in the center of the disc (less problematic). SEM micrograph of metallic samples made by SPS and polished by P800 sandpaper: (I) SS 316L, (J) Cu pure, (K) Cu15Ni8Sn, and $(\mathbf{L}) \mathrm{CuNi} 2 \mathrm{SiCr}$
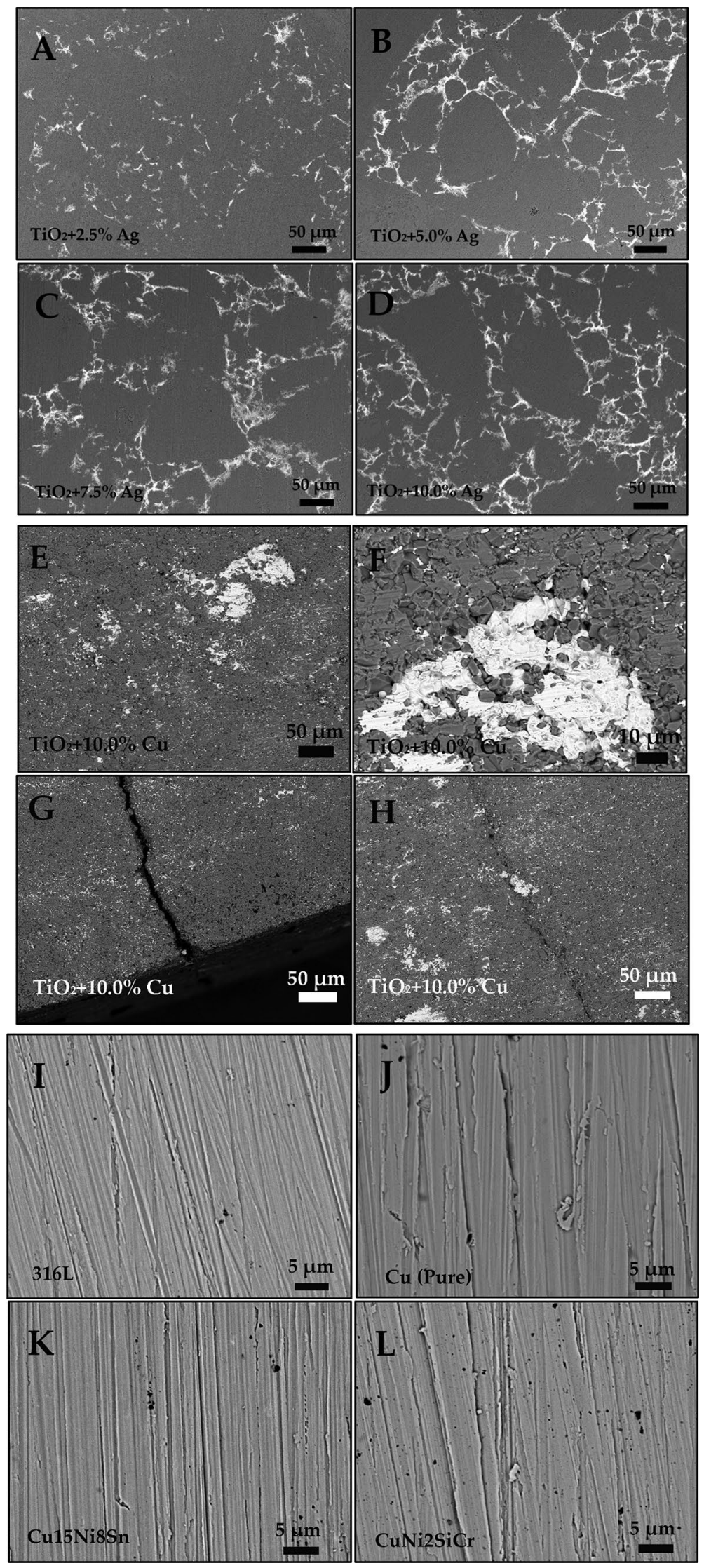


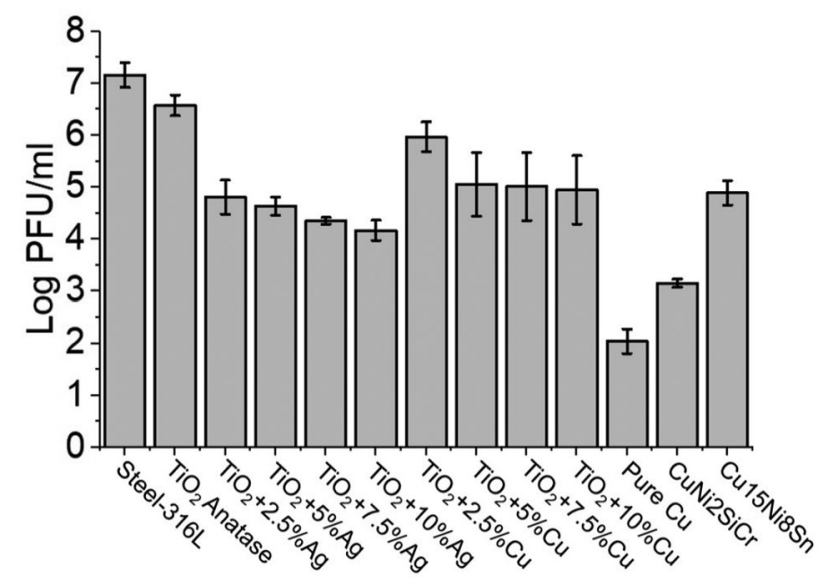

Fig. 7 Viral titers of phage Phi6 recovered after $15 \mathrm{~min}$ of contact with discs' surfaces. Average values \pm standard deviations $(n \geq 3)$ are given

$\mathrm{TiO}_{2}+\mathrm{Ag}(2.5-10 \% \mathrm{Ag})$ and $\mathrm{TiO}_{2}+\mathrm{Cu}(2.5-10 \% \mathrm{Cu})$ series. Recently, Phi6 virus contact inhibition by different surfaces was demonstrated, and viral titers obtained from swabbing $\mathrm{TiO}_{2}+10 \% \mathrm{Ag}+10 \% \mathrm{Cu}$ surfaces were significantly lower compared to those from control $\mathrm{TiO}_{2}$ or steel discs [48]. A very good virucidal activity was observed for pure $\mathrm{Cu}$ and $\mathrm{CuNi} 2 \mathrm{SiCr}$ discs. Altogether, these data indicate that the new materials fabricated via hybrid powder bed fusion and powder metallurgy routes have a very good virucidal potential against the bacteriophage Phi6.

\subsection{Surface effectiveness on virucidal properties}

Surface conditions are one of the most important factors affecting virucidal properties. To better characterize the surface properties of different materials, we determined the surface free energy using the contact angle measurement method. The surface free energy of the fabricated surfaces varied from 20.2 to $55.8 \mathrm{~mJ} / \mathrm{m}^{2}$ (Table 1). Increasing the $\mathrm{Ag}$ concentration in the $\mathrm{TiO}_{2}$ ceramics resulted in a significant increase in surface free energy. In contrast, the effect of adding $\mathrm{Cu}$ ions was less pronounced. For all samples, the dispersive component contributed most to the surface free energy, suggesting that the hydrophobic interactions between the virus membrane and the surface are important for virus adhesion.
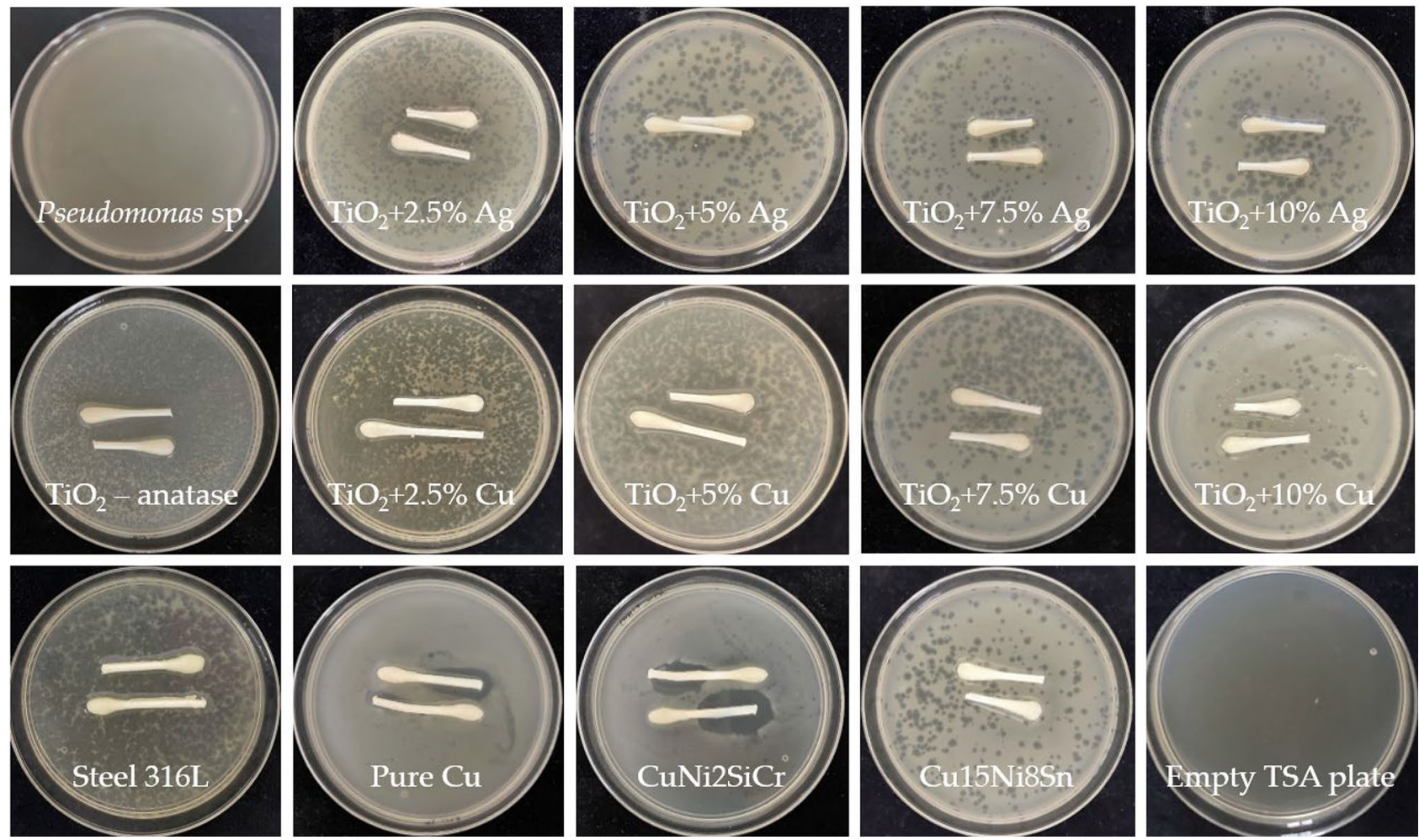

Fig. 8 Residual viruses remaining on swabs. Wet and dry cotton swabs with residual bacteriophage Phi6 in contact with host bacterium Pseudomonas sp. (DSM 21,482) on agar plates. When no virus is present on swabs, Pseudomonas sp. can grow and form confluent biofilms on agar plates. When residual viruses are present on swabs, a clear zone of no bacterial growth or individual plaques scattered around the plate are visible 
Table 1 Surface free energy (SFE) of fabricated surfaces. The experimental error has been estimated to $10 \%$

\begin{tabular}{|c|c|c|c|}
\hline Discs & $\operatorname{SFE}\left(\mathbf{m J} / \mathbf{m}^{2}\right)$ & $\begin{array}{l}\text { Dispersive ( } \mathbf{m} \mathbf{J} / \\
\left.\mathbf{m}^{2}\right)\end{array}$ & Polar $\left(\mathbf{m} J / \mathbf{m}^{2}\right)$ \\
\hline Steel 316L & $38.38 \pm 3.84$ & $31.47 \pm 3.15$ & $6.91 \pm 0.69$ \\
\hline $\mathrm{TiO}_{2}$ anatase & $36.35 \pm 3.64$ & $29.52 \pm 2.95$ & $6.83 \pm 0.68$ \\
\hline $\mathrm{TiO}_{2}+2.5 \% \mathrm{Cu}$ & $20.15 \pm 2.02$ & $20.13 \pm 2.01$ & $0.02 \pm 0.002$ \\
\hline $\mathbf{T i O}_{2}+5 \% \mathrm{Cu}$ & $24.09 \pm 2.41$ & $24.08 \pm 2.41$ & $0.01 \pm 0.001$ \\
\hline $\mathrm{TiO}_{2}+7.5 \% \mathrm{Cu}$ & $24.91 \pm 2.49$ & $23.24 \pm 2.32$ & $1.67 \pm 0.17$ \\
\hline $\mathrm{TiO}_{2}+10 \% \mathrm{Cu}$ & $27.35 \pm 2.74$ & $27.25 \pm 2.73$ & $0.10 \pm 0.01$ \\
\hline Pure Cu & $24.51 \pm 2.45$ & $24.33 \pm 2.43$ & $0.18 \pm 0.02$ \\
\hline CuNi2SiCr & $34.04 \pm 3.41$ & $33.23 \pm 3.32$ & $0.80 \pm 0.08$ \\
\hline Cu15Ni8Sn & $30.34 \pm 3.03$ & $30.30 \pm 3.03$ & $0.04 \pm 0.01$ \\
\hline $\mathrm{TiO}_{2}+2.5 \% \mathrm{Ag}$ & $41.69 \pm 4.17$ & $35.32 \pm 3.53$ & $6.38 \pm 0.64$ \\
\hline $\mathbf{T i O}_{2}+5 \% \mathrm{Ag}$ & $42.55 \pm 4.23$ & $37.41 \pm 3.74$ & $5.14 \pm 0.51$ \\
\hline $\mathrm{TiO}_{2}+7.5 \% \mathrm{Ag}$ & $46.06 \pm 4.61$ & $31.90 \pm 3.19$ & $14.16 \pm 1.42$ \\
\hline $\mathrm{TiO}_{2}+10 \% \mathrm{Ag}$ & $55.76 \pm 5.58$ & $35.60 \pm 3.56$ & $20.16 \pm 2.02$ \\
\hline
\end{tabular}

\subsection{Fabrication of prototype virucidal elevator buttons}

To test whether new virucidal materials can be combined into structurally compact ceramic-metal composites, we designed and fabricated a prototype elevator button as an example of the potential application of the new virucidal materials. Such virucidal surfaces would significantly improve sanitation in public places. As shown in Fig. 9, 3D printed elevator buttons can be produced using the hybrid powder bed fusion and powder metallurgy (Ti6Al4V or CuNi2SiCr matrix made by SLM with the ability to fill by SPS in the next step). The layer thickness for all 3D-printed lattices in this study was $25 \mu \mathrm{m}$ (each $1 \mathrm{~mm}$ height of scaffold requires 40 times recoater wiping and laser sintering).

In the design of the lattice scaffold (Fig. 10), it is possible to define the starting and finishing configuration of

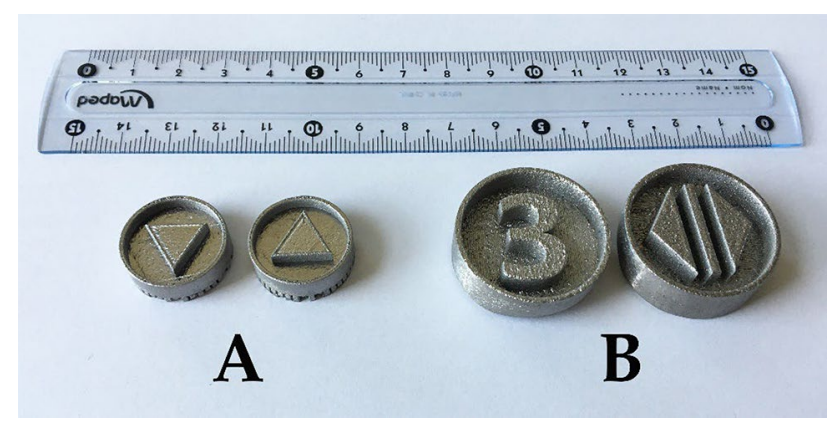

Fig. 9 (A) $20 \mathrm{~mm}$ diameter $(5 \mathrm{~mm}$ bulk metal (Ti6Al4V here, but possible $\mathrm{CuNi} 2 \mathrm{SiCr}$ ) at the bottom and $5 \mathrm{~mm}$ dented for filling with ceramic $\left(\mathrm{TiO}_{2}-\mathrm{Cu}\right.$ or $\mathrm{TiO}_{2}-\mathrm{Ag}$ in SPS process), and (B) $30 \mathrm{~mm}$ height (10 $\mathrm{mm}$ bulk metal at the bottom and $10 \mathrm{~mm}$ dented for filling with ceramic in SPS process) applied for elevator buttons the cross-sections. Here, $\mathrm{CuNi} 2 \mathrm{SiCr}$ and Ti6Al4V metal lattices have an identical type ( 4 cross-sectional diamondtype) but different ending layers due to the SLM process. The smaller unit cell (closer struts in cross-section) can induce pores in the ceramic, while larger cells may result in cracks. Pores and cracks in the filled ceramic are only affected by the SPS conditions (pressure, temperature, and time). However, this does not affect the hardness or consolidation in SPS. The representative composites with either $\mathrm{CuNi} 2 \mathrm{SiCr}$ or Ti6Al4V metal lattices filled with $\mathrm{TiO}_{2}+10 \% \mathrm{Ag}$ are shown in Fig. 11. The SLM technique provides the possibility to apply both bulk/solid or lattice/scaffold structures, depending on the application. To improve the mechanical properties, a heating step with $10 \mathrm{MPa}$ pressure and a temperature ramp $(6 \mathrm{~min}$ temperature rise, $100{ }^{\circ} \mathrm{C} / \mathrm{min}$ rate from 300 to $900{ }^{\circ} \mathrm{C}$ ) was performed during SPS (pre-sintering). The advantage of this step, especially for the $\mathrm{Cu}$-based lattice is the transformation of the stuck/unmelted particles (caused by PBF) into consolidated struts, and the result is a drastic increase in hardness as well as a slight increase in strut diameter. The $\mathrm{CuNi} 2 \mathrm{SiCr}-\mathrm{TiO}_{2}+110 \% \mathrm{Ag}$ material was sintered at $700{ }^{\circ} \mathrm{C}$. The Ti6Al4V-TiO ${ }_{2}+10 \%$ Ag material, on the other hand, was sintered at $900{ }^{\circ} \mathrm{C}$ due to the higher melting point of titanium compared to copper. The pressure and dwelling time were identical for both composites and were $20 \mathrm{MPa}$ and $12 \mathrm{~min}$, respectively.

Figure 12 shows SEM micrographs of cell size and lattice strut at the ceramic boundary for the two lattices. The ceramics trapped between the struts may have some pores or shallow cracks due to the low-pressure and low-temperature (LPLT) conditions of SPS (see Fig. 12A), but the metalceramic bonding and hardness in both zones were acceptable. For the $\mathrm{CuNi} 2 \mathrm{SiCr}-\mathrm{TiO}_{2}+10 \% \mathrm{Ag}$ composite, the hardness was in the range of 184-200 for $\mathrm{TiO}_{2}$ and $78 \mathrm{~kg} /$ $\mathrm{mm}^{2}$ for $\mathrm{Cu}$ in HV500 (Vickers hardness test performed separately for both the filled ceramic and the metal matrix). The hardness for the $\mathrm{Ti}^{6} \mathrm{Al} 4 \mathrm{~V}-\mathrm{TiO}_{2}+10 \%$ Ag composite was higher, $402-458$ for $\mathrm{TiO}_{2}$ and 420 for Ti6Al4V, respectively $\left(\mathrm{kg} / \mathrm{mm}^{2}\right.$ in HV500).

In general, the bond between metallic lattice (here $\mathrm{CuNi}$ $2 \mathrm{SiCr}$ ) and $\mathrm{TiO}_{2}+10 \% \mathrm{Ag}$ is dependent on the melting points of metallic alloys. The sintering conditions in SPS, especially the temperature, are defined based on the lowest melting point of the components, i.e., the metal. Due to the high conductivity and lower melting point of the copper alloy (compared to titanium dioxide), unmelted particles of the lattice could re-melt. After the SLM process, some raw unmelted particles remained and stucked to the metal lattices (see $[16,17]$ ), which can be re-sintered during the SPS process, resulting in stronger struts and composite structures. The $\mathrm{Ti} 6 \mathrm{Al} 4 \mathrm{~V}-\mathrm{TiO}_{2}+10 \% \mathrm{Ag}$ composite exhibited higher hardness than the $\mathrm{CuNi} 2 \mathrm{SiCr}-\mathrm{TiO}_{2}+10 \%$ 
Fig. 10 (A) CAD model for SLM process of copper-based ( 3 cell height, $20 \mathrm{~mm}$ diameter and $0.1 \mathrm{~mm}$ solid part at the bottom), (B) CuNi2SiCr lattice structure with $0.5 \mathrm{~mm}$ strut size, $2 \times 2 \times 2 \mathrm{~mm}^{3}$ cell size, and $6 \mathrm{~mm}$ height (it is the proper height for using in SPS), (C) SEM micrograph of the lattice structure, and (D) SEM micrograph of the strut

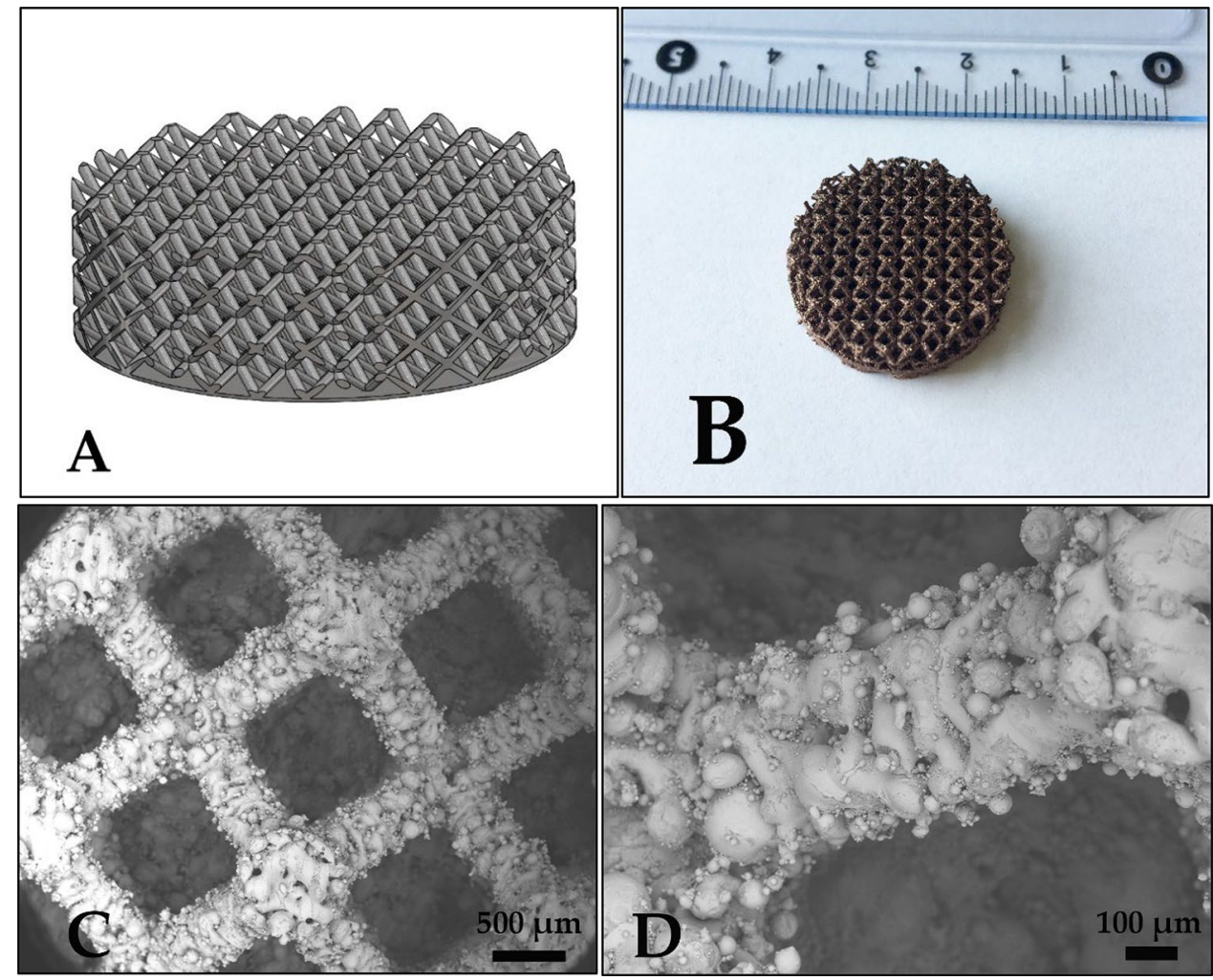

Ag composite in both zones, metallic (due to the higher strength-to-weight ratio of Ti compared to $\mathrm{Cu}$ ) and ceramic (due to the higher melting point of Ti6Al4V compared to $\mathrm{CuNi2SiCr}$, which allows the sintering temperature to be increased during the SPS).

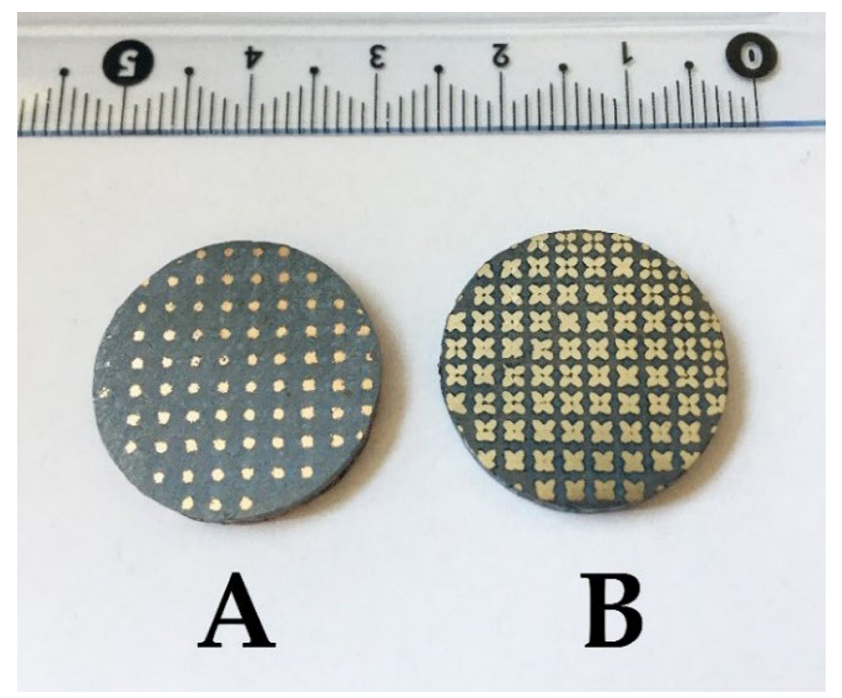

Fig. 11 Photograph of metallic lattice scaffolds embedded with ceramics. (A) $\mathrm{CuNi} 2 \mathrm{SiCr}$ lattice filled with $\mathrm{TiO}_{2}+10 \%$ Ag ceramics; (B) Ti6Al4V metal lattice filled with $\mathrm{TiO}_{2}+10 \% \mathrm{Ag}$. strut size $0.5 \mathrm{~mm}$, cell size $2 \mathrm{~mm}, 20 \mathrm{~mm}$ sample diameter, and $6 \mathrm{~mm}$ sample height is applied for both $\mathrm{CuNi2SiCr}$ and Ti6Al4V lattices
The high virucidal effects of the $\mathrm{TiO}_{2}+\mathrm{Ag}$ series are attributed to the increasing concentrations of $\mathrm{Ag}$ ions as dopants. As the concentration of dopant Ag ions increased, the disc hardness decreased (the same SPS parameters were used for all $\mathrm{TiO}_{2}+\mathrm{Ag}$ series). The Ag ions may affect on photocatalytic performance, phase transition, and wettability of titanium oxides, see, e.g., [49, 50]. Increased concentration of $\mathrm{Cu}$ dopant ions increased the cracking of the disc without substantial increase of the virucidal effect. Compared to pure $\mathrm{Cu}$ metal, the addition of $\mathrm{Ni}$ and $\mathrm{Cr}$ to $\mathrm{CuNi} 2 \mathrm{SiCr}$ alloy decreased the virucidal effect on Phi 6. We investigated the effect of $\mathrm{NiCl}_{2}$ and $\mathrm{K}_{2} \mathrm{Cr}_{2} \mathrm{O}_{7}$ salts on Phi6. $\mathrm{Ni}$ ions had no significant virucidal effect on Phi6 in the concentration range of 0.001 to $0.1 \mathrm{M}$. On the other hand, $\mathrm{Cr}$ ions decreased the virus titer from $10^{10}$ to $10^{7} \mathrm{PFU}$ in the same concentration range [48]. Compared to pure $\mathrm{Cu}$ metal, the new $\mathrm{CuNi} 2 \mathrm{SiCr}$ alloy exhibits improved hardness and stiffness, while other mechanical properties such as thermal-electrical conductivity and corrosion resistance are largely preserved [39].

\subsection{Virucidal elevator panel design}

To improve virucidal surfaces, new materials will need to be produced in the future, such as iron-based $316 \mathrm{~L}$ alloys (with improved corrosion resistance), aluminumbased AlSi10Mg alloys (to obtain lightweight structures), 
Fig. 12 SEM micrograph of (A) cell size of CuNi2SiCr$\mathrm{TiO}_{2}+10 \%$ Ag composite (shallow cracks detected in the diagonal direction trapped between the metallic struts), (B) $\mathrm{CuNi} 2 \mathrm{SiCr}$ lattice strut and $\mathrm{TiO}_{2}+10 \%$ Ag ceramic boundary, C) cell size of Ti6Al4V$\mathrm{TiO}_{2}+10 \%$ Ag composite, and D) Ti6Al4V lattice strut and $\mathrm{TiO}_{2}+10 \% \mathrm{Ag}$ ceramic boundary
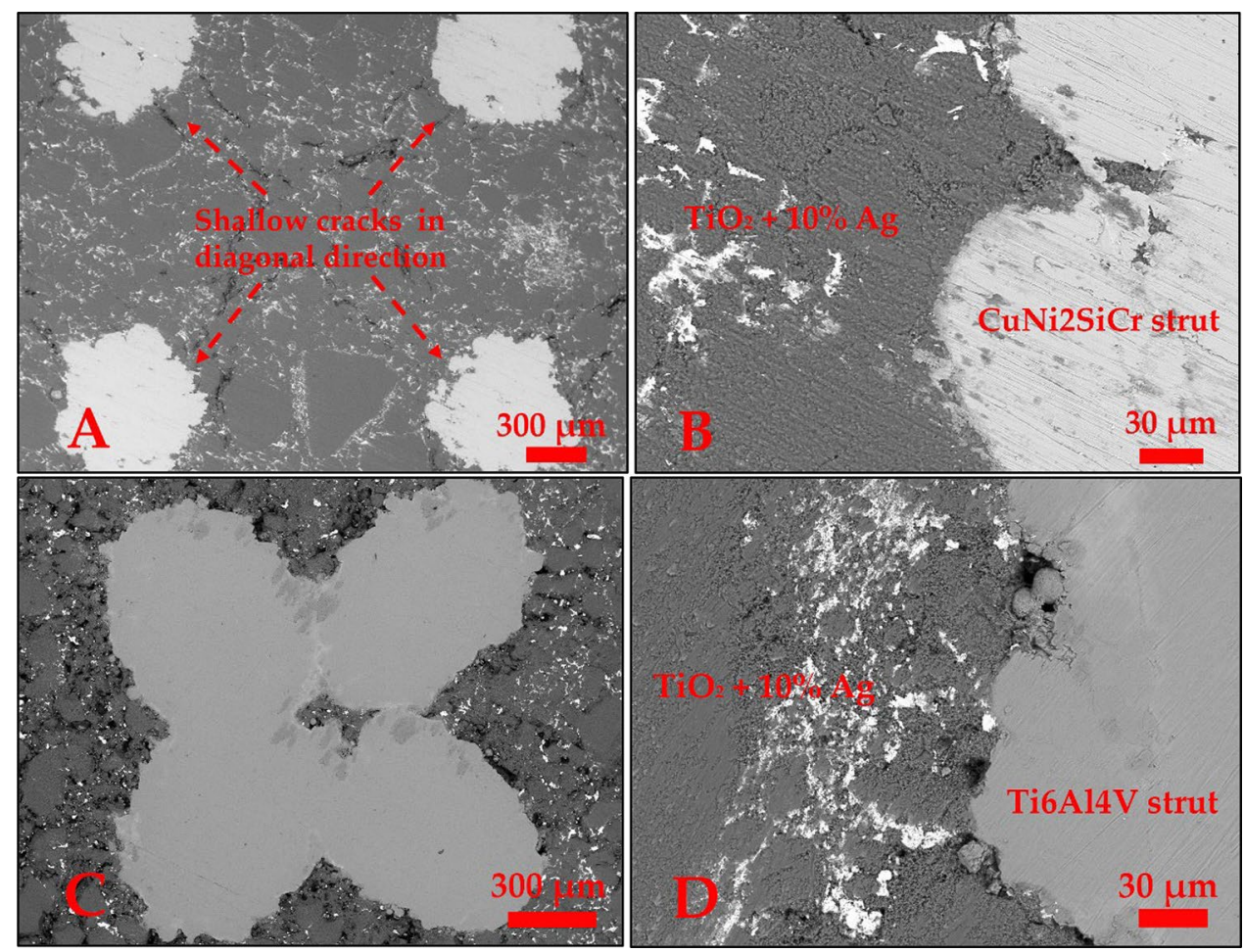

cobalt-based CoCr28Mo6 (for high-temperature resistance), titanium-based Ti6A14V or Ti22A125Nb (for the medical industry), copper-based $\mathrm{Cu} 2 \mathrm{NiSiCr}$ or $\mathrm{Cu} 15 \mathrm{NiSn}$ (for thermal-electrical conductivity), and nickel-based Inconel718 (with improved tensile strength). The prototype elevator panel is shown in Fig. 13. The question is how much hardness, corrosion, or impact resistance is needed for surfaces that can be touched by the public and whether pores/densification affect the quality of the materials. For our applications, strong force resistance is not needed. The main idea is that ceramic, although prone to cracking can be reinforced in metal-ceramic composite materials and may withstand high compression/impact and corrosion (see Rahmani et al. [1,34]). There is a wide range of materials that can be used for the panel and bottoms (including filled ceramics) that are investigated in this study.

The virucidal button prototypes were additively manufactured with a layer thickness of $50 \mu \mathrm{m}$ (for faster prototyping) using a SLM280 device (from SLM Solutions AG, Germany); for the desired higher compressive strength and impact resistance, the layer thickness should be reduced to $25 \mu \mathrm{m}$ (Fig. 14, sample A). To achieve a higher consolidation rate, it is better to design graphite punches/molds to provide maximum pressure in the ceramic region during the SPS process and uniaxial compression (Fig. 14, sample B). The SLM-made sample is without post-processing (polishing or coating, etc.) because it is filled by ceramics (here with $\mathrm{TiO}_{2}+10 \% \mathrm{Ag}$ ) in the next step during the SPS process.

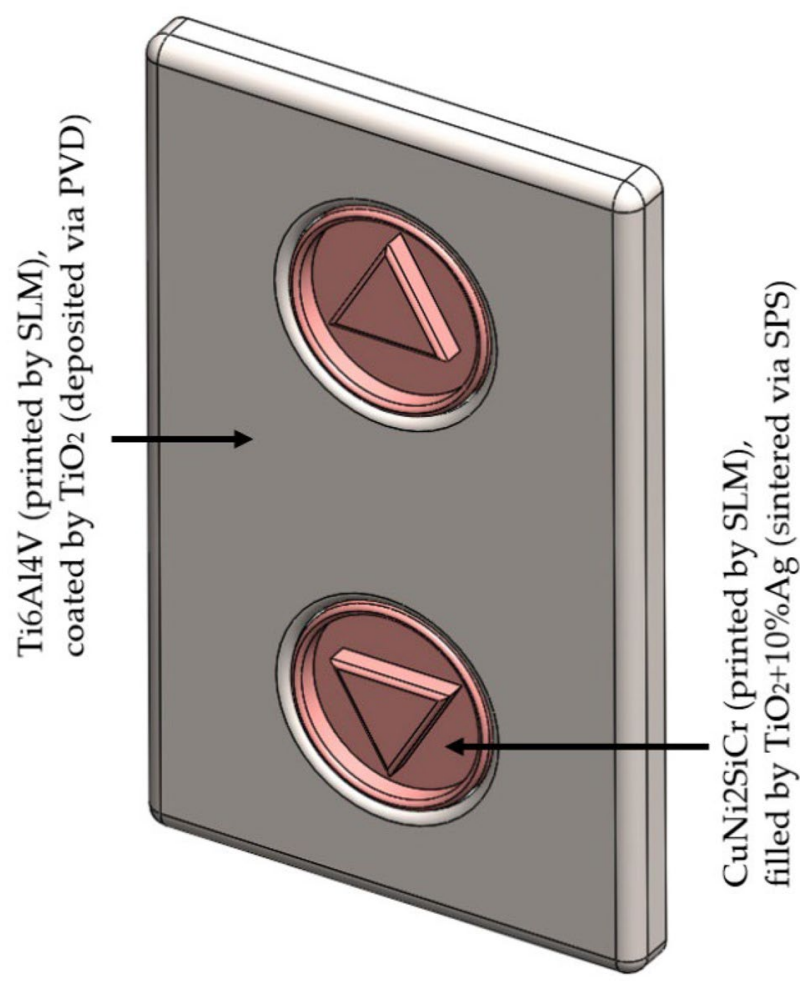

Fig. 13 Elevator panel conception; CAD model of copper-based (3Dprinted of CuNi2SiCr or Cu15Ni8Sn, Ti6Al4V, or Ti22Al25Nb) for SLM process in $20 \mathrm{~mm}$ diameter and $20 \mathrm{~mm}$ height $(10 \mathrm{~mm}$ bulk metal in the bottom and $10 \mathrm{~mm}$ dented for filling by ceramic in SPS) for elevator buttons. Later they will be filled and sintered by $\mathrm{Ag}+\mathrm{TiO}_{2}$ or $\mathrm{Cu}+\mathrm{TiO}_{2}$ during the SPS process with demanded antimicrobial/antiviral/antiadhesion properties. Abbreviations in the figure: SLM, selective laser melting; PVD, physical vapor deposition; SPS, spark plasma sintering 
Fig. 14 Elevator bottom conception (A) SLM-fabricated Ti6Al4V, (B) SPS-consolidated $\mathrm{TiO}_{2}+10 \%$ Ag. The circle zones in photographs are zoomed by SEM to show the micrograph of both metallic tip (C) and ceramic regions (D)

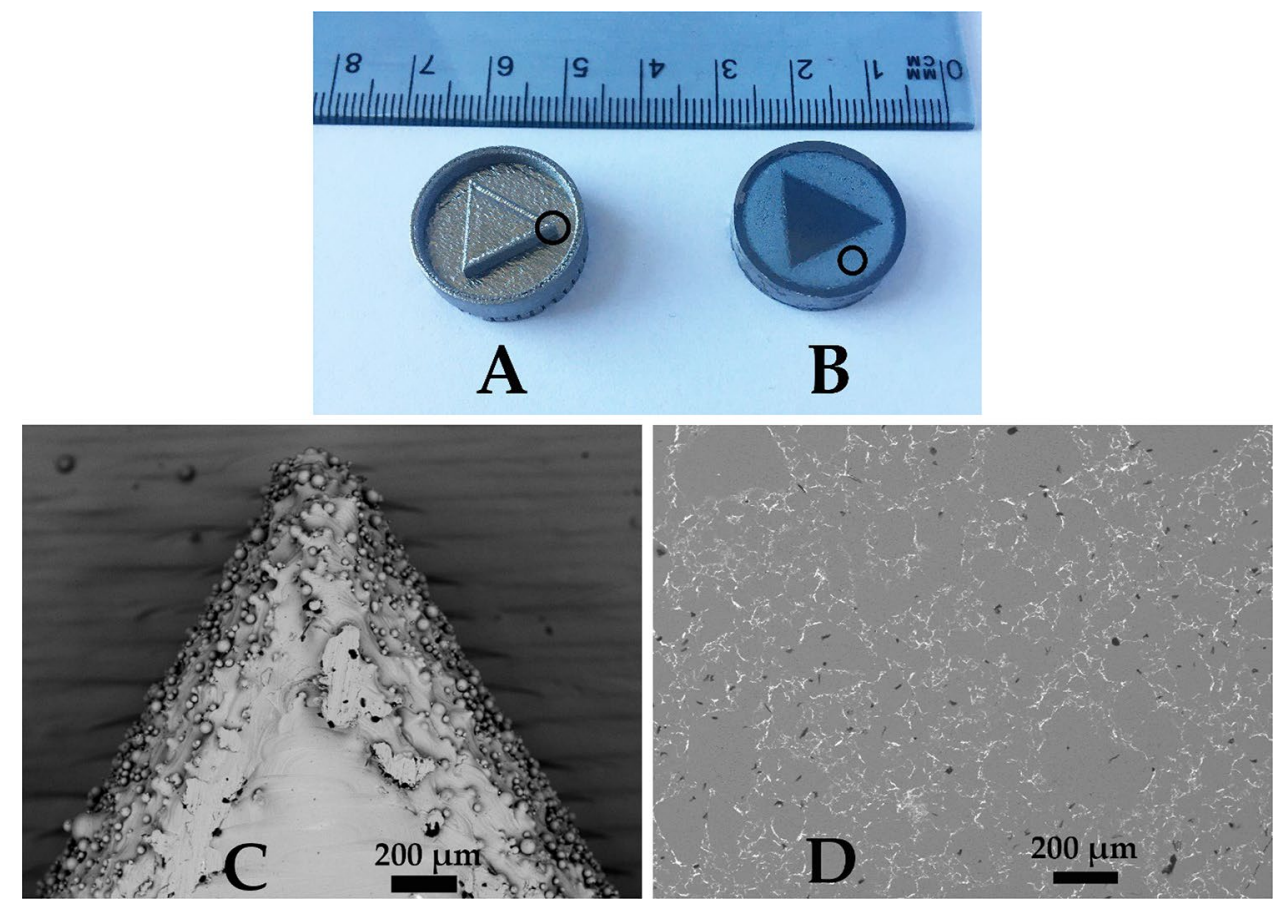

\section{Conclusions}

In this study, SLM and SPS hybrid techniques were used to fabricate new composite materials that have very good potential as virucidal surfaces. The newly fabricated materials have acceptable mechanical properties for their use in various devices. A very good virucidal effect against bacteriophage Phi6 was observed for pure $\mathrm{Cu}$ and $\mathrm{CuNi}$ $2 \mathrm{SiCr}$ discs in comparison to $316 \mathrm{~L}$ steel. To prove the concept that a metal scaffold filled with virucidal ceramic can be fabricated, we have made new ceramic-metal button prototypes. For this purpose, a $\mathrm{CuNi} 2 \mathrm{SiCr}$ metal scaffold made by SLM was filled with $\mathrm{TiO}_{2}+10 \%$ Ag ceramic using SPS, which improved the mechanical properties of metal and ceramic combined the virucidal properties of $\mathrm{Ag}$ and $\mathrm{Cu}$ materials. The addition of $\mathrm{Ag}$ to $\mathrm{TiO}_{2}$ decreased the hardness of the ceramic materials, and the addition of $\mathrm{Cu}$ increased cracking. Compared with the control steel discs, the $\mathrm{TiO}_{2}+10 \%$ Ag ceramic and CuNi2SiCr metal discs reduced phage titers for 4 logs. The results suggest that $\mathrm{TiO}_{2}+10 \% \mathrm{Ag}$ is preferred over $\mathrm{TiO}_{2}+10 \% \mathrm{Cu}$ due to better virucidal properties and the absence of cracking. The new virucidal composites have tailored mechanical material properties suitable for different applications, such as elevator buttons, doorknobs, rails, etc. The ability to rapidly produce efficient virucidal surfaces that can have a complex shape and are frequently touched in public places could have a great impact on our society and our coexistence with viruses.
Author contribution Conceptualization, R.R. and K.M.; methodology, R.R., M.B., and D.S.; investigation, R.R. and K.M.; writing-original draft preparation, R.R. and K.M.; writing-review and editing, M.B., D.S., and K.G.P.; supervision, D.S; funding acquisition, M.B. and K.G.P.

Funding This study was supported by the Estonian Ministry of Education and Research, European Regional Development Fund ASTRA6-6, and by Slovenian Research Agency grants P2-0263 and P4-0116.

\section{Declarations}

Ethics approval Not applicable.

Consent to participate Not applicable.

Consent for publication Not applicable.

Conflict of interest The authors declare no competing interests.

\section{References}

1. Rahmani R, Rosenberg M, Ivask A, Kollo L (2019) Comparison of mechanical and antibacterial properties of $\mathrm{TiO}_{2} / \mathrm{Ag}$ ceramics and $\mathrm{Ti} 6 \mathrm{Al} 4 \mathrm{~V}-\mathrm{TiO}_{2} / \mathrm{Ag}$ composite materials using combining SLM-SPS techniques. Metals 9:874

2. Rahmani R, Antonov M, Kamboj N (2019) Modelling of impact-abrasive wear of ceramic, metallic, and composite materials. Proc Est Acad Sci 68:191-197

3. Rahmani R, Antonov M, Kollo L, Holovenko Y, Prashanth KG (2019) Mechanical behavior of Ti6Al4V scaffolds filled with $\mathrm{CaSiO}_{3}$ for implant applications. Appl Sci 9:3844

4. Kamboj N, Rodríguez MA, Rahmani R, Prashanth KG, Hussainova I (2019) Bioceramic scaffolds by additive 
manufacturing for controlled delivery of the antibiotic vancomycin. Proc Est Acad Sci 68:185-190

5. Weiss C, Carriere M, Fusco L, Capua I, Regla-Nava JA, Pasquali M, Scott JA, Vitale F, Unal MA, Mattevi C, Bedognetti D, Merkoçi A, Tasciotti E, Yilmazer A, Gogotsi Y, Stellacci F, Delogu LG (2020) Toward nanotechnology-enabled approaches against the COVID-19 Pandemic. ACS Nano 14:6383-6406

6. Van Doremalen N, Bushmaker T, Morris DH, Holbrook MG, Gamble A, Williamson BN, Tamin A, Harcourt JL, Thornburg NJ, Gerber SI, Lloyd-Smith JO, De Wit E, Munster VJ (2020) Aerosol and surface stability of SARS-CoV-2 as compared with SARS-CoV-1. N Engl J Med 382:1564-1567

7. Hutasoit N, Kennedy B, Hamilton S, Luttick A, Rashid RAR, Palanisamy S (2020) Sars-CoV-2 (COVID-19) inactivation capability of copper-coated touch surface fabricated by coldspray technology. Manufacturing letters 25:93-97

8. Wang J, Zhoua XL, Li J, Brochu M, Zhao YF (2020) Microstructures and properties of SLM-manufactured $\mathrm{Cu}-15 \mathrm{Ni}-8 \mathrm{Sn}$ alloy. Addit Manuf 31:100921

9. Ikeshoji TT, Nakamura K, Yonehara M, Imai K, Kyogoku H (2018) Selective laser melting of pure copper. JOM 70:396-400

10. Deng C, Kang J, Feng T, Feng Y, Wang X, Wu P (2018) Study on the selective laser melting of $\mathrm{CuSn}_{10}$ powder. Materials 11:614

11. Nefedova E, Koptev V, Bobikova AS, Cherepushkina V, Mironova T, Afonyushkin V, Shkil N, Donchenko N, Kozlova Y, Sigareva N, Davidova N, Bogdanchikova N, Pestryakov A, Toledano-Magaña Y (2021) The infectious bronchitis coronavirus pneumonia model presenting a novel insight for the SARS-CoV-2 dissemination route. Vet Sci 8:239

12. Gaikwad S, Ingle A, Gade A, Rai M, Falanga A, Incoronato N, Russo L, Galdiero S, Galdiero M (2013) Antiviral activity of mycosynthesized silver nanoparticles against herpes simplex virus and human parainfluenza virus type 3 . Int $\mathbf{J}$ Nanomed 8:4303-4314

13. Morris D, Ansar M, Speshock J, Ivanciuc T, Qu Y, Casola A, Garofalo R (2019) Antiviral and immunomodulatory activity of silver nanoparticles in experimental RSV infection. Viruses 8:732

14. Trefry JC, Wooley DP (2013) Silver nanoparticles inhibit vaccinia virus infection by preventing viral entry through a macropinocytosisdependent mechanism. J Biomed Nanotechnol 9:1624-1635

15. Zhang XF, Liu ZG, Shen W, Gurunathan S (2016) Silver nanoparticles: synthesis, characterization, properties, applications, and therapeutic approaches. Int J Mol Sci 17:1534

16. Rahmani R, Brojan M, Antonov M (2020) Lightweight 3D printed Ti6A14V-AlSi10Mg hybrid composite for impact resistance and armor piercing shielding. J Market Res 9:13842-13854

17. Rahmani R, Brojan M, Antonov M, Prashanth KG (2020) Perspectives of metal-diamond composites additive manufacturing using SLM-SPS and other techniques for increased wear-impact resistance. Int J Refract Met Hard Mater 88:105192

18. Vidaver AK, Koski RK, Van Etten JL (1973) Bacteriophage phi6: a lipid-containing virus of Pseudomonas phaseolicola. J Virol 11:799-805

19. Mindich L, Nemhauser I, Gottlieb P, Romantschuk M, Carton J, Frucht S, Strassman J, Bamford DH, Kalkkinen N (1988) Nucleotide sequence of the large double-stranded RNA segment of bacteriophage phi 6: genes specifying the viral replicase and transcriptase. J Virol 62:1180-1185

20. McGraw T, Mindich L, Frangione B (1986) Nucleotide sequence of the small double-stranded RNA segment of bacteriophage phi 6: novel mechanism of natural translational control. J Virol 58:142-151

21. Gottlieb P, Metzger S, Romantschuk M, Carton J, Strassman J, Bamford DH, Kalkkinen N, Mindich L (1988) Nucleotide sequence of the middle dsRNA segment of bacteriophage phi
6: placement of the genes of membrane-associated proteins. Virology 163:183-190

22. Laurinavicius S, Käkelä R, Bamford DH, Somerharju P (2004) The origin of phospholipids of the enveloped bacteriophage phi6. Virology 326:182-190

23. Prussin AJ, Schwake DO, Lin K, Gallagher DL, Buttling L, Marr LC (2018) Survival of the enveloped virus phi6 in droplets as a function of relative humidity, absolute humidity, and temperature. Appl Environ Microbiol 84:1-10

24. Whitworth C, Mu Y, Houston H, Martinez-Smith M, Noble-Wang J, Coulliette-Salmond A, Rose L (2020) Persistence of bacteriophage Phi 6 on porous and nonporous surfaces and the potential for its use as an Ebola virus or coronavirus surrogate. Appl Environ Microbiol 86:1-11

25. Adcock NJ, Rice EW, Sivaganesan M, Brown JD, Stallknecht DE, Swayne DE (2009) The use of bacteriophages of the family Cystoviridae as surrogates for $\mathrm{H} 5 \mathrm{~N} 1$ highly pathogenic avian influenza viruses in persistence and inactivation studies. J Environ. Sci. Health Part A. Tox Hazard Subst Environ Eng 44:1362-1366

26. Fedorenko A, Grinberg M, Orevi T, Kashtan N (2020) Survival of the enveloped bacteriophage Phi6 (a surrogate for SARS-CoV-2) in evaporated saliva microdroplets deposited on glass surfaces. Sci Rep 10:1-10

27. Thijs L, Verhaeghe F, Craeghs T, Humbeeck JV, Kruth JP (2010) A study of the microstructural evolution during selective laser melting of Ti-6Al-4V. Acta Mater 58:3303-3312

28. Zhang B, Li Y, Bai Q (2017) Defect formation mechanisms in selective laser melting: a review. Chin J Mech Eng 30:515-527

29. Gorji NE, O'Connor R, Brabazon D (2021) XPS, SEM, AFM, and nano-indentation characterization for powder recycling within additive manufacturing process. IOP Conference Series: Materials Science and Engineering 1182:012025

30. Chawake N, Pinto LD, Srivastav AK, Akkiraju K, Murty BS, Kottada RS (2014) On Joule heating during spark plasma sintering of metal powders. Scripta Mater 93:52-55

31. Saheb N, Iqbal Z, Khalil A, Hakeem AS, Al-Aqeeli N, Laoui T, Al-Qutub A, Kirchner R (2012) Spark plasma sintering of metals and metal matrix nanocomposites: a review. nanomaterial properties: size and shape dependencies 983470

32. Kamboj N, Kazantseva J, Rahmani R, Rodríguez MA, Hussainova I (2020) Selective laser sintered bio-inspired silicon-wollastonite scaffolds for bone tissue engineering. Mater Sci Eng C 116:111223

33. Rahmani R, Antonov M, Kollo L (2019) Selective laser melting of diamond-containing or postnitrided materials intended for impactabrasive conditions: experimental and analytical study. Adv Mater Sci Eng 4210762

34. Rahmani R, Antonov M, Kollo L (2019) wear resistance of (diamond-Ni)-Ti6Al4V gradient materials prepared by combined selective laser melting and spark plasma sintering techniques. Adv Tribol 5415897

35. Tran TQ, Chinnappan A, Lee JKY, Loc NH, Tran LT, Wang G, Kumar VV, Jayathilaka WADM, Ji D, Doddamani M, Ramakrishna S (2019) 3D printing of highly pure copper. Metals 9:756

36. Klengel S, Krombholz A, Schwedler O, Busch H (2021) Material characterization of copper structures for electronic systems manufactured by selective laser melting (SLM). IEEE 23rd European Microelectronics and Packaging Conference \& Exhibition (EMPC)

37. http://www.fct-systeme.de/en. Accessed on 10/01/2022

38. Rahmani R, Antonov M, Prashanth KG (2021) The impact resistance of highly densified metal alloys manufactured from gasatomized pre-alloyed powders. Coatings 11:216

39. https://www.slm-solutions.com/products-and-solutions/powders. Accessed on 10/01/2022

40. Holovenko Y, Kollo L, Saarna M, Rahmani R, Soloviova T, Antonov M, Prashanth KG, Cygan S, Veinthal R (2020) Effect of 
lattice surface treatment on performance of hardmetal-titanium interpenetrating phase composites. Int J Refract Met Hard Mater 86:105087

41. Kaelble DH (1970) Dispersion-polar surface tension properties of organic solids. J Adhesion 2:66-81

42. Owens D, Wendt R (1969) Estimation of the surface free energy of polymers. J Appl Polym Sci 13:1741-1747

43. Rabel W (1971) Einige Aspekte der Benetzungstheorie und ihre Anwendung auf die Untersuchung und Veränderung der Oberflächene genschaften von Polymeren. Farbe und Lack 77:997-1005

44. Pinheiro LAM, Pereira C, Frazão C, Balcão VM, Almeida A (2019) Efficiency of phage $\varphi 6$ for biocontrol of Pseudomonas syringae pv. syringae: an in vitro preliminary study. Microorganisms 9:286

45. Katz A, Alimova A, Futerman E, Katz G, Wei H, Gottlieb P (2011) Bacteriophage $\varphi 6$-structure investigated by fluorescence stokes shift spectroscopy. Photochem Photobiol 88:304-310
46. Adams MH, Bacteriophages (1959) Interscience publishers, Inc. New York, USA

47. Lin Q, Lim JYC, Xue K, Yew PYM, Owh C, Chee PL, Loh XJ (2020) Sanitizing agents for virus inactivation and disinfection. VIEW 1:1-26

48. Molan K, Rahmani R, Krklec D, Brojan M, Stopar D (2022) Phi 6 bacteriophage inactivation by metal salts, metal powders, and metal surfaces. Viruses 14:204

49. Moongraksathum B, Chien MY, Chen YW (2019) Antiviral and antibacterial effects of silver-doped $\mathrm{TiO}_{2}$ prepared by the peroxo sol-gel method. J Nanosci Nanotechnol 19:7356-7362

50. Mosquera AA, Albella JM, Navarro V, Bhattacharyya D, Endrino JL (2016) Effect of silver on the phase transition and wettability of titanium oxide films. Sci Rep 6:32171

Publisher's Note Springer Nature remains neutral with regard to jurisdictional claims in published maps and institutional affiliations. 